\title{
Dispersal of semi-fleshy fruits to rock crevices by a rock-restricted rodent
}

\section{AUTHORS: \\ Joseph D.M. White ${ }^{1}$ \\ Jeremy J. Midgley ${ }^{1}$ \\ AFFILIATION: \\ ${ }^{1}$ Department of Biological \\ Sciences, University of \\ Cape Town, Cape Town, \\ South Africa}

\section{CORRESPONDENCE TO: \\ Joseph White}

EMAIL:

josephwhite16@gmail.com

DATES:

Received: 16 May 2017

Revised: 11 Sep. 2017

Accepted: 12 Oct. 2017

\section{KEYWORDS:}

seed dispersal; directed dispersal; Heeria argentea; rock outcrops; fire refugia

\section{HOW TO CITE:}

White JDM, Midgley JJ. Dispersal of semi-fleshy fruits to rock crevices by a rock-restricted rodent. S Afr J Sci. 2017;113(11/12), Art. \#2017-0159, 5 pages. http://dx.doi.org/10.17159/ sajs.2017/20170159

\section{ARTICLE INCLUDES:}

$\checkmark$ Supplementary material

$\times$ Data set

FUNDING:

National Research Foundation (South Africa)

(c) 2017. The Author(s). Published under a Creative Commons Attribution Licence.
Seed dispersal allows successive generations of plants to be mobile in space and time. Heeria argentea's unusual fruit and its ubiquity in extremely rocky habitats, suggests that this tree requires a specialist disperser. We therefore investigated the dispersal ecology of $H$. argentea and Hartogiella schinoides. We found $M$. namaquensis rapidly removed $H$. argentea and $H$. schinoides fruits, moving them short distances within and between rock outcrops, and consumed only the pericarps. Birds were observed consuming $H$. schinoides, but not $H$. argentea fruits, suggesting $M$. namaquensis is its sole, specialist disperser. Most $H$. argentea seeds (65\%) with removed pericarps germinated successfully, while intact fruits did not. We show rock outcrops represent fire refugia, allowing $H$. argentea trees to grow to large sizes, with small stems and a co-occurring, wind-dispersed tree, Widdringtonia nodiflora found away from these sites. This rodent-tree mutualism is perhaps the clearest global example of directed dispersal and shows that these endemic trees are highly adapted for survival in the southwestern Cape habitat and are not tropical relicts.

\section{Significance:}

- The fruits of rock-restricted Cape trees are directly dispersed by rock rats to rock outcrops. This is the first description of rodent dispersal of fleshy fruits in South Africa.

- This species-specific interaction allows for rapid germination of seeds and protection from frequent fires for adults. This rodent-tree mutualism is perhaps the clearest global example of directed seed dispersal.

\section{Introduction}

Seed dispersal allows plants, via their seeds, to be mobile in space and time. The spatio-temporal locations at which seeds arrive have a major influence on the subsequent fitness of offspring, as location is a major determinant of seed and seedling survival. Many small patches of fire-avoiding forest exist in a wider sea of fire-prone shrublands and savanna across South Africa. In the southwestern Cape, these forests are restricted to growing in extremely rocky habitats, such as on cliffs and amongst rock outcrops and screes. ${ }^{1}$

The dynamics of these forests are different to that of the adjacent shrublands (known as fynbos) where post-fire recruitment from long-lived seed banks of non-fleshy fruits dominates. ${ }^{2}$ For example, many Proteaceae as well as Widdringtonia nodiflora (mountain cypress; Cupressaceae) are serotinous trees with dry, wind-dispersed seeds that grow in the open shrublands. In contrast, forest tree fruits are typically soft and non-dormant. Heeria argentea (rockwood) and Hartogiella schinoides (spoonwood) (sensu Islam et al. ${ }^{3}$ ) are important constituents of these forests. Heeria argentea has pale, yellow-green, leathery-coated fruits up to $30 \mathrm{~mm}$ in diameter with a $3 \mathrm{~mm}$ thin, fleshy pericarp surrounding a single, soft, chlorophyllous seed (Figure 1a,b). Similarly, $H$. schinoides seeds are chlorophyllous but the fruit is smaller (diameter $=15 \mathrm{~mm}$ ) and more visually distinct being a dark, red colour (Figure 1c,d).

Birds are unlikely dispersers of $H$. argentea, because the fruits are unattractive and unrewarding. Marloth ${ }^{4}$ suggested that Procavia capensis (rock hyrax) is the primary disperser of $H$. argentea. Presumably his main evidence was their overlapping distributions, both being rock-restricted, and the unusual fruit. Although there are no data, others have cited this hypothesis. ${ }^{5,6}$ We investigated the dispersal ecology of these fruiting species based on Marloth's hypothesis.

\section{Methods}

Data were collected in April and May 2016 at seven sites in the Limietberg Nature Reserve $\left(33.620355^{\circ} \mathrm{S}\right.$, $\left.19.106678^{\circ} \mathrm{E}\right)$ in the southwestern Cape, South Africa. $H$. argentea fruits were collected directly off trees in April 2016. The fruits ripen and fall to the ground over several months in the austral summer (personal observation). We placed $5-10 \mathrm{H}$. argentea fruits at depots for 3 days, with six depots per site $\left(n_{\text {total }}=\right.$ six sites; $n_{\text {total }}=330$ fruits); four sites were in rock outcrops and two sites were in adjacent non-rocky proteoid shrublands. To locate moved fruits, each was attached to a reverse-wound bobbin with fast-setting non-toxic glue. At each depot (placed \pm 50 $\mathrm{m}$ apart), we used a LTL Acorn 6210M remotely activated camera trap (Shenzen LTL Acorn Electronics Co., Shenzen, Guangdong, China) to monitor animal-fruit interactions. Cameras were set to record one photograph, immediately followed by a 30-s video. Each time an animal interacted with a novel fruit or entered/left the field of view it was considered a new event. For $H$. schinoides, we followed a similar, scaled-down experiment, placing out six depots at a single site with 10 fruits per depot. No camera traps were used in this experiment.

Germination trials were conducted on intact and handled $H$. argentea fruits ( $n=40$ of each) over 6 weeks at the University of Cape Town's glasshouse. Fruits were placed in individual trays on the surface of a potting soil medium and watered once a week. We used a chi-squared test in the $\mathrm{R}$ programming language $\mathrm{f}^{7}$ to compare overall germination of fruits. 

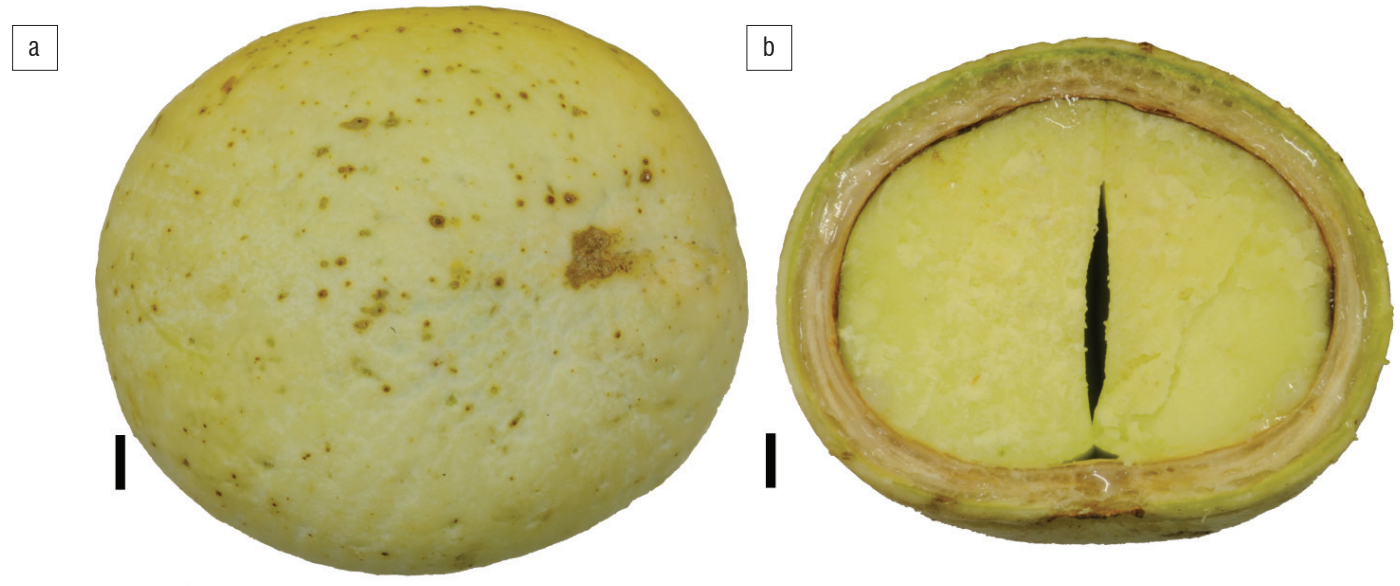
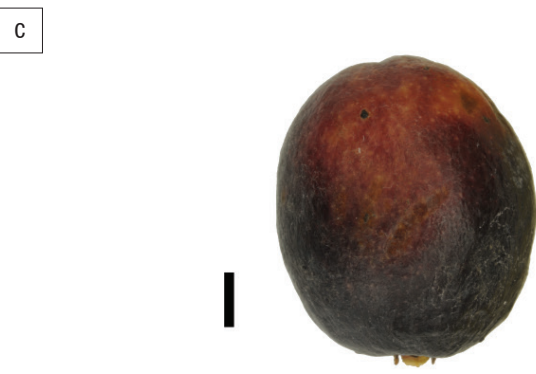

d

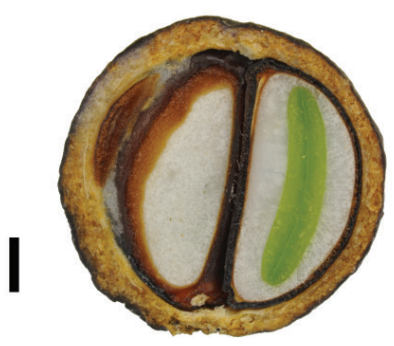

Scale bar $=2 \mathrm{~mm}$

Figure 1: Intact and cross-sectioned fruits of $(a, b)$ Heeria argentea and $(c, d)$ Hartogiella schinoides, showing the thin, fleshy pericarps and chlorophyllous endosperm/embryo.

We investigated fire impacts on $H$. argentea and $W$. nodiflora individuals 1 year post-fire. We measured the basal diameter $(\mathrm{mm})$ of $H$. argentea and $W$. nodiflora adults in relation to distance within and from the outer edge of rock outcrops (defined here as a collection of rocks $\geq 2 \mathrm{~m}^{2}$ ). We estimated the fire damage by rating the proportion of the canopy dead in $\mathrm{H}$. argentea and W. nodiflora. All individuals were surveyed within a 0.6-ha area that included both shrublands and rock outcrops. Beta regression ${ }^{8}$ in $\mathrm{R}^{7}$ was used to determine the relationships between tree size, distance to rock outcrops and fire damage. Reported values are mean \pm standard deviation.

\section{Results}

\section{Rock outcrops}

Within only 3 nights, $6.63 \pm 3.85$ fruits per depot were removed (total $=66 \% ; n=159 / 240$ ). Of these 159 fruits, $31 \%$ were located and collected, and $40 \%$ were not retrieved, but were tracked to a minimum distance until the thread either snapped or was dislodged. The remaining $29 \%$ were considered lost, likely as a result of thread failure.

Of the 159 moved fruits that left a thread trail, we determined that $90 \%$ of these had been moved at least $0.3 \mathrm{~m}$ into rock outcrops $3.26 \pm 3.77 \mathrm{~m}$ from the initial depot. Of these dispersed fruits, $92 \%$ had more than $75 \%$ of the pericarp removed (Figure 2a,b). None of the chlorophyllous seeds were visibly damaged. Seeds with pericarps did not germinate $(n=0 / 40)$ whereas seeds with removed pericarps did $\left(n=26 / 40,65 \% ; X^{2}=31.5\right.$, d.f. $=1, p<0.001$; Figure 2c).

Despite observation of their droppings within $50 \mathrm{~m}$ of all sites, only one rock hyrax was recorded on camera at one depot and this individual did not interact with the fruits. Instead, Micaelamys namaquensis (Namaqua rock rat) was the most frequently viewed small mammal on camera trap observations $(n=151)$ and was the only animal viewed removing fruits in the rock outcrop sites ( $n=100$ events) (Supplementary video 1). No bird visitation was documented. Fruits were typically moved out of the camera field of view but at one site we observed a Namaqua rock rat consuming the pericarp (Supplementary video 2). We also viewed the following carnivores on the camera trap observations: Genetta tigrina (Cape genet) and Galerella pulverulenta (Cape grey mongoose), neither of which interacted with fruits.

Dispersal of $H$. schinoides appeared to follow the same pattern. Within 3 days, $80 \%$ of fruits $\left(n_{\text {total }}=60\right)$ were removed and $58 \%$ of these were located $(n=28)$, with $93 \%$ of those moved to rock outcrops and $68 \%$ had theirfull pericarp removed. We incidentally observed Onychognathus morio (red-wing starlings) feeding on $\mathrm{H}$. schinoides fruits.

\section{Shrublands}

Fruits were rarely moved $(2.25 \pm 2.31$ per depot; $16 \%$ of $n=90)$ at shrubland sites, with most located $(n=11 / 14)$. Fruits occasionally showed the pericarp slightly consumed $(n=11)$, with the pericarp never fully removed. All moved fruits were discarded in the open on the soil surface. Camera trap observations showed that the four small mammal species recorded usually ignored fruits (Supplementary video 3 ). These species included Rhadbomys pumilio (four-striped grass mouse) $(n=92)$, Otomys irroratus (vlei rat) $(n=46)$ and Acomys subspinosus (Cape spiny mouse) $(n=14)$, as well as occasionally Hystrix africaeaustralis (Cape porcupine), with only $R$. pumilio occasionally interested in $H$. argentea fruits (removing $n=10$ fruits).

\section{Plant distribution and fire damage}

Heeria argentea trees were distributed on the margin or within rock outcrops (64\%), and $36 \%$ were found away from rock outcrops. Large adult $H$. argentea trees were typically found far within rock outcrops $(-2.65 \pm 2.89 \mathrm{~m})$ and lacked any fire damage. Small $H$. argentea trees were mostly found away from rock outcrops $(7.83 \pm 8.94 \mathrm{~m})$ and often received full top-kill from fire damage (53\% of $n=139$ trees)(see Figure 3). W. nodiflora was never found within rocky refugia and always experienced full top-kill from fire damage. Both basal diameter (estimate \pm s.d. $=-0.04 \pm 0.01, z=-3.57, p<0.001)$ and distance relative to rock outcrops $(0.06 \pm 0.01, \mathrm{z}=4.58, p<0.001)$ were significant predictors of fire damage in $H$. argentea (pseudo $R^{2}=0.46$ ). 


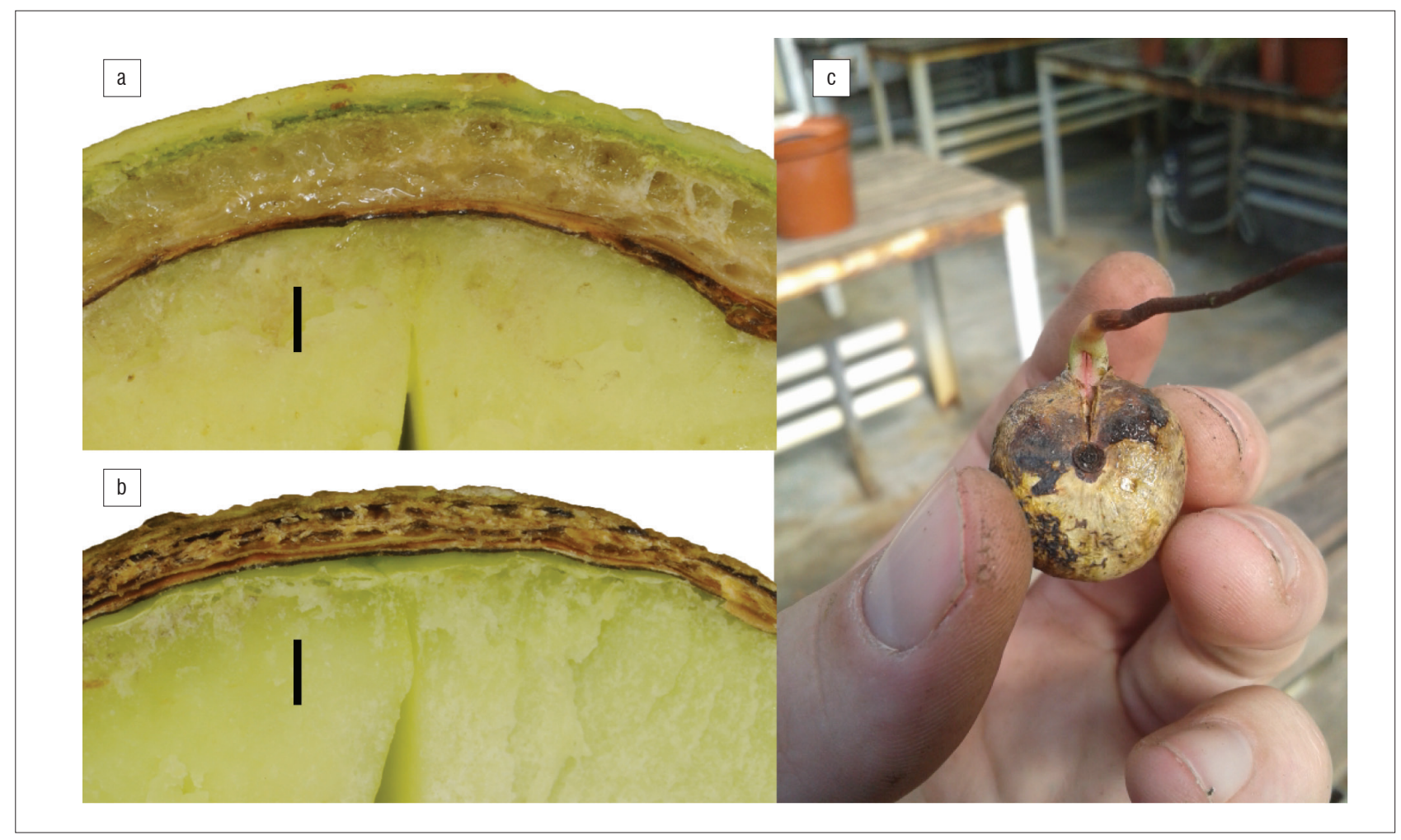

$(a, b)$ Scale bar $=1 \mathrm{~mm}$

Figure 2: Cross-section of Heeria argentea fruits that are (a) intact and (b) with the pericarp removed showing the fleshy layer that Namaqua rock rats consume. (c) A germinated seed with the radicle breaking through a fruit without the leathery pericarp.

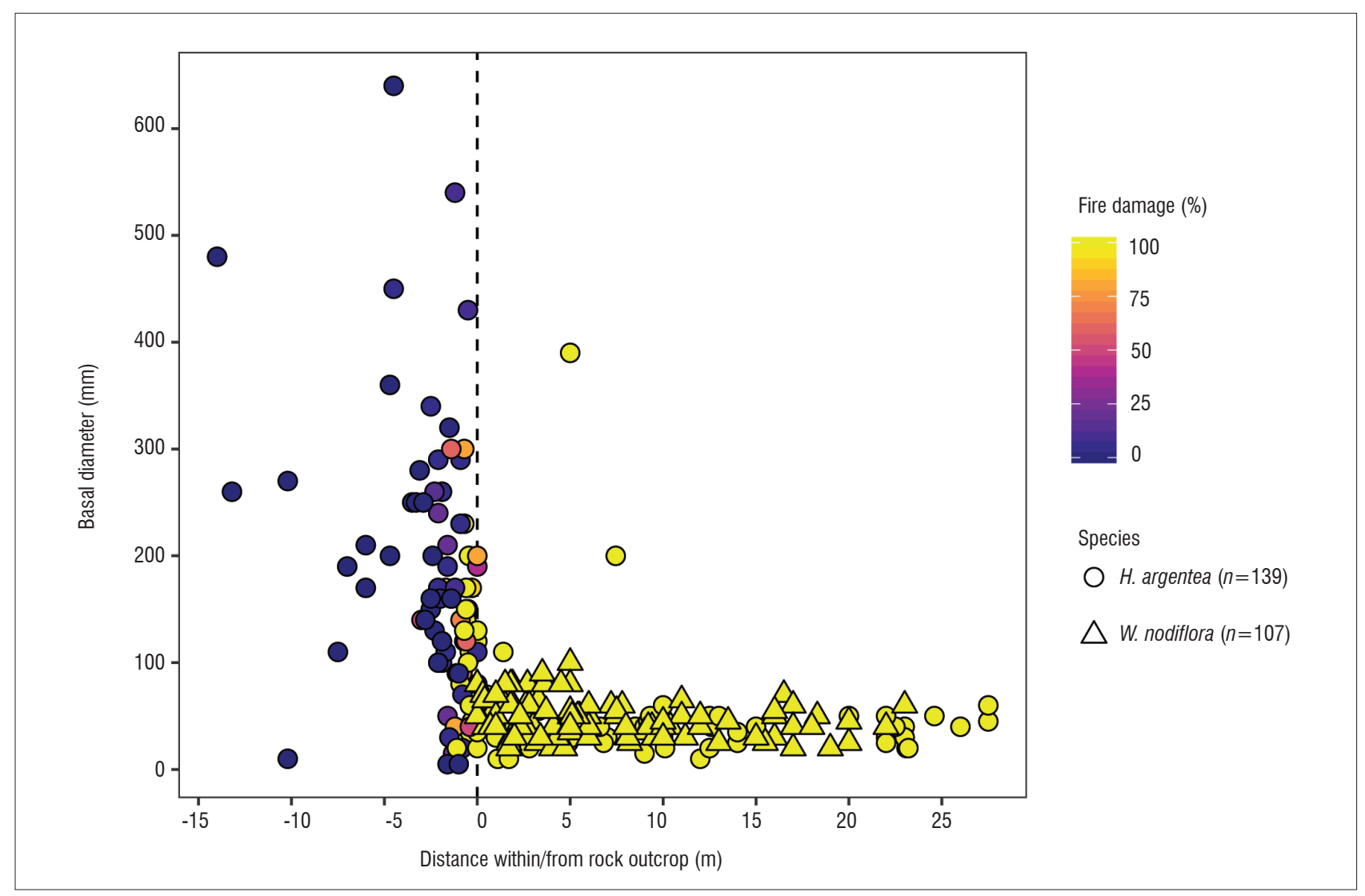

Figure 3: The proportion of canopy damage from a recent fire to Heeria argentea and Widdringtonia nodiflora trees of different sizes within (negative) and from (positive) rock outcrops. 


\section{Discussion}

The rapid rate of fruit removal and pericarp consumption showed that the fruits of both $H$. argentea and $H$. schinoides are highly attractive and rewarding to Namaqua rock rats. Our findings thus lead to the rejection of Marloth's ${ }^{4}$ original hypothesis. As the seeds have no dormancy, germination is not stimulated by fire, or its products, unlike most seeds in fire-prone ecosystems. ${ }^{2} \mathrm{H}$. argentea is thus dependent on rock rats for dispersal and rapid initiation of germination. Avoiding predation by carnivores may explain why Namaqua rock rats take fruits to narrow and concealed crevices before consuming the pericarp layer.

The fruit dispersal patterns of $H$. schinoides also suggest Namaqua rock rat dispersal. Their fruits are smaller and dark red in colour - likely an adaptation for bird frugivory. We observed bird frugivory on $\mathrm{H}$. schinoides fruits, but never observed birds feeding on $\mathrm{H}$. argentea. The fruit of Heeria is likely too large for the gape of most local frugivorous birds and, as the seed is soft, pecking, biting or ingestion could destroy it. Further, birds would not likely disperse the seeds into crevices. As Namaqua rock rats also feed on $\mathrm{H}$. schinoides, they are likely generalist frugivores.

The significance of dispersal to rock outcrops is not immediately apparent, as these may be poor sites for initial seedling growth. The large seed, and consequent large energy stores, of $H$. argentea may facilitate some growth in deep shade (Figure 4). Large $H$. argentea trees were mostly found within rocky refugia where they experienced almost no fire damage. In contrast, small stems were found away from fire refugia and generally experienced full canopy death. This difference suggests that individuals in less rock-protected sites are condemned to small size and likely reduced reproductive capacity as a result of frequent top-kill and consequent basal resprouting after repeated burning. Wind dispersal of W. nodiflora seeds appears to prevent arrival in rocky refugia because no individuals were observed within rock outcrops. Unlike $H$. argentea, all $W$. nodiflora trees experienced full top-kill during the recent fire (Figure 3).

Aspects of the $H$. argentea-Namaqua rock rat interaction are unusual. Firstly, rodent dispersal of fleshy fruits is a novel dispersal mechanism in the Cape. Rodents may be dispersers of non-fleshy, dry seeds typically by scatter-hoarding. ${ }^{9,10}$ Namaqua rock rat dispersal of $H$. argentea differs from most other small mammal dispersal. In other rodent frugivory cases, the fruits may be partially damaged..$^{11-14}$ Globally, rodent frugivory, in which the seed is not ingested and left undamaged, has only been documented in a few studies. ${ }^{13,15}$ Exotic rodents have been documented to disperse seeds while only consuming the pericarp. ${ }^{13}$ By consuming only the pericarp, Namaqua rock rats still achieve a reward while leaving the seed intact. Secondly, this is an example of directed dispersal in which fruits disproportionately arrive at non-random, fireprotected destinations that are highly favourable sites for survival. ${ }^{16}$

The three classic examples of directed dispersal are somewhat controversial. Mistletoe seedlings can only establish on thin, sun-exposed branches with only specific bird species, such as Dicaeum hirundinaceum (mistletoebirds), considered able to disperse seeds to these sites. That generalist birds, marsupials ${ }^{17}$, explosive seed release ${ }^{18}$ and the wind ${ }^{19}$ also effectively disperse mistletoe seeds weakens this argument. Myrmecochory (ant-dispersal) has been suggested as a mechanism for directed dispersal to ant nests (localised sites of high nutrients in nutrient-poor shrublands), but some evidence suggests otherwise..$^{20,21}$ Scatter-hoarding by rodents can be 'directed' to sites of low adult conspecifics. ${ }^{22}$ However, the benefit of these sites is escape from seed predators. $H$. argentea fruit dispersal is possibly the clearest global example of directed dispersal - too short-distance, site-specific and beneficial to established plants (rather than seedlings), to be explained by escape of seed or seedling predators or by colonisation of prime sites by seedlings. ${ }^{16}$

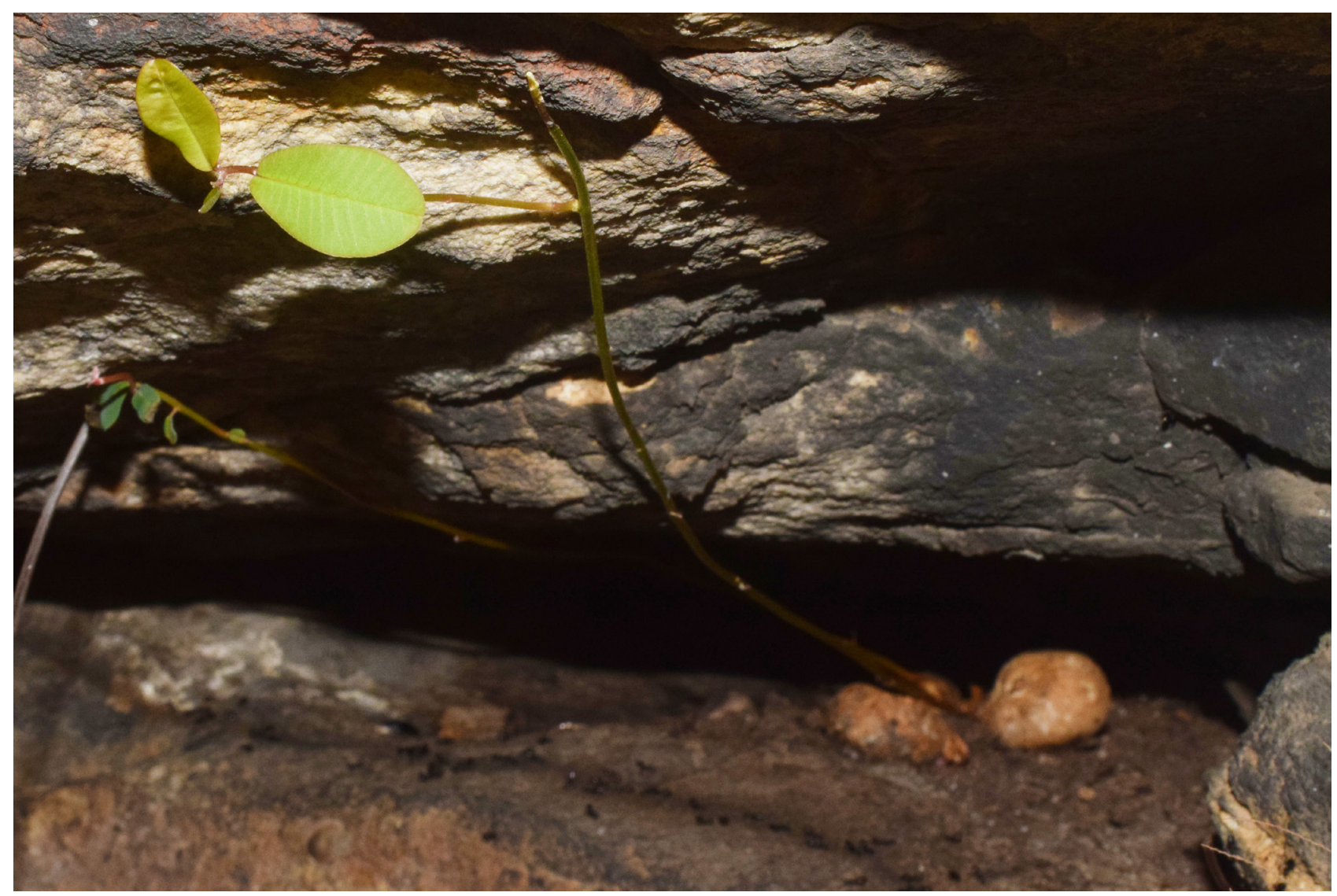

Figure 4: A Heeria argentea seedling emerges from a dark, rocky crevice at Limietberg Nature Reserve. 


\section{Acknowledgements}

We thank Deon Rossouw of CapeNature for permission to work in Limietberg Nature Reserve. We also thank the South African National Research Foundation for funding. J.E. Quince provided assistance with data collection.

\section{Authors' contributions}

J.J.M. conceptualised the study. Both authors contributed to data collection and writing. J.D.M.W. did the data analyses.

\section{References}

1. Moll EJ, McKenzie B, McLachlan D. A possible explanation for the lack of trees in fynbos, Cape Province, South Africa. Biol Conserv. 1980;17:221228. https://doi.org/10.1016/0006-3207(80)90057-9

2. Le Maitre DC, Midgley JJ. Plant reproductive ecology. In: Cowling R, editor. The ecology of fynbos: Nutrients, fire and diversity. Oxford: Oxford University Press; 1992. p. 135-174.

3. Islam MB, Simmons MP, Archer RH. Phylogeny of the Elaeodendron group (Celastraceae) inferred from morphological characters and nuclear and plastid genes. Syst Bot. 2006;31(3):512-524. https://doi. org/10.1600/036364406778388610

4. Marloth R. The flora of South Africa. Vol. II, Section II. Cape Town: Darter Bros. \& Co.; 1925

5. Von Teichman I, Van Wyk AE. Taxonomic significance of pericarp and seed structure in Heeria argentea (Thunb.) Meisn. (Anacardiaceae), including reference to pachychalazy and recalcitrance. Bot J Linn Soc. 1996;122:335352. https://doi.org/10.1111/j.1095-8339.1996.tb02080.x

6. Van Wyk B, Van Wyk P. Field guide to trees of southern Africa. Cape Town: C. Struik; 1997.

7. R Core Team. R: A language and environment for statistical computing. Vienna: R Foundation for Statistical Computing; 2016

8. Cribari-Neto F, Zeilis A. Beta Regression in R. J Stat Softw. 2010;34:1-24. https://doi.org/10.18637/jss.v034.i02

9. Vander Wall SB. Food hoarding in animals. Chicago, IL: University of Chicago Press; 1990

10. White JDM, Bronner GN, Midgley JJ. Camera-trapping and seed-labelling reveals widespread granivory and scatter-hoarding of nuts by rodents in the Fynbos Biome. African Zool. 2017;52(1):31-41. https://doi.org/10.1080/15 627020.2017.1292861
11. Steele MA, Knowles T, Bridle K, Simms EL. Tannins and partial consumption of acorns: Implications for dispersal of oaks by seed predators. Am Midl Nat. 1993;130(2):229-238. https://doi.org/10.2307/2426123

12. Mendoza E, Dirzo R. Seed tolerance to predation: Evidence from the toxic seeds of the buckeye tree (Aesculus californica; Sapindaceae). Am J Bot. 2009:96(7):1255-1261. https://doi.org/10.3732/ajb.0800297

13. Shiels $A B$, Drake DR. Are introduced rats (Rattus rattus) both seed predators and dispersers in Hawaii? Biol Invasions. 2011;13:883-894. https://doi. org/10.1007/s10530-010-9876-7

14. Loayza AP, Carvajal DE, García-Guzmán P, Gutierrez JR, Squeo FA. Seed predation by rodents results in directed dispersal of viable seed fragments of an endangered desert shrub. Ecosphere. 2014;5(4):1-9. https://doi. org/10.1890/ES13-00283.1

15. Feer F, Henry O, Forget P-M, Gayot M. Frugivory and seed dispersal by terrestrial mammals. In: Bongers F, Charles-Dominique P, Forget $P$, Théry $\mathrm{M}$, editors. Nouragues: Dynamics and plant-animal interactions in a neotropical rainforest. Dordrecht: Springer; 2001. p. 227-232. https://doi. org/10.1007/978-94-015-9821-7_21

16. Wenny DG. Advantages of seed dispersal: A re-evaluation of directed dispersal. Evol Ecol Res. 2001;3:51-74.

17. Amica G, Aizen MA. Mistletoe seed dispersal by a marsupial. Nature 2000;408:929-930. https://doi.org/10.1038/35050170

18. DeBruyn RAJ, Paetkau M, Ross KA, Godfrey DV, Friedman CR. Thermogenesistriggered seed dispersal in dwarf mistletoe. Nat Commun. 2015;6(6262):15. https://doi.org/10.1038/ncomms7262

19. Tercero-Bucardo N, Kitzberger T. Establishment and life history characteristics of the southern South American mistletoe Misodendrum punctulatum (Misodendraceae). Rev Chil Hist Nat. 2004;77:509-521. https://doi. org/10.4067/S0716-078X2004000300010

20. Rice B, Westoby M. Evidence against the hypothesis that ant-dispersed seeds reach nutrient-enriched microsites. Ecology. 1986;67(5):1270-1274. https:// doi.org/10.2307/1938682

21. Bond AWJ, Stock WD. The costs of leaving home: Ants disperse myrmecochorous seeds to low nutrient sites. Oecologia. 1989;81(3):412417. https://doi.org/10.1007/BF00377092

22. Hirsch B, Kays R, Pereira VE, Jansen PA. Directed seed dispersal towards areas with low conspecific tree density by a scatter-hoarding rodent. Ecol Lett. 2012:15:1423-1429. https://doi.org/10.1111/ele.12000 